Article - Biological and Applied Sciences

\title{
Growth and Immune Response of Pangasius hypophthalmus Fed Diets Containing Seaweed Extracts as Immunostimulant
}

\section{Francis Nuestro Baleta ${ }^{1}$}

https://orcid.org/0000-0002-5266-1893

\section{Jonathan Mallillin Bolaños ${ }^{1 \star}$}

https://orcid.org/0000-0002-6017-5916

${ }^{1}$ Isabela State University, Institute of Fisheries, San Fabian, Echague, Isabela, Philippines Received: 2018.02.15; Accepted: 2019.07.08.

*Correspondence: jonathan_bolanos@yahoo.com; Tel.: +63-93-58165931 (J.M.B.)

\section{HIGHLIGHTS}

- $\quad$ S. oligocystum HWE increased growth performance of $P$. hypophthalmus.

- HWE of S. oligocystum improved immune response of $P$. hypophthalmus.

- HWE of S. oligocystum have potential as natural immunostimulant for finfish.

\begin{abstract}
Growth and immune response of Pangasius hypophthalmus were evaluated after feeding the fish with diets containing hot-water extracts (HWE) of Sargassum oligocystum as immunostimulant at 100,300 , and $500 \mathrm{mg} \mathrm{kg}^{-1}$ diet. Basal diet for $P$. hypophthalmus served as the control. The experimental diets were administered for 12 weeks. At the end of the feeding experiment, growth and haematological profile of fish were evaluated. Result showed that final weight, weight gain, daily growth rate and feed conversion ratio were significantly increased in the fish that received 300 and $500 \mathrm{mg} \mathrm{kg}^{1}$ HWE of S. oligocystum. Evaluation of the haematological profile showed that white blood cells red blood cells, hemoglobin, hematocrit and platelet of $P$. hypophthalmus that received the HWE of $S$. oligocystum were significantly higher than the control group. Overall, our results indicate that the use of $S$. oligocystum HWE improves growth and haematological profile in $P$. hypophthalmus.
\end{abstract}

Keywords: Growth performance; Hot water extract; Pangasius hypophthalmus; Sargassum oligocystum. 


\section{INTRODUCTION}

Disease outbreaks were recently identified as a result of intensification and expansion in aquaculture production [1], with consequent harmful effect on the industry's economic development and serious economic losses [2]. Commercial approaches were used to control fish diseases, such as the use of anti-microbial agents and vaccination, however, they have limited success in the prevention of/or treatment of aquatic diseases. Antibiotics and other chemotherapeutics have been used to control fish and shellfish diseases can result in the development of drug-resistant pathogens [3], environmental treat [4], and accumulation of residues in fish. Therefore, looking for less-harmful approaches and more environment-friendly treatments became of premium importance in aquaculture management. Immunostimulation, or enhancement of the immune system of an organism, seems to be the most promising methods in increasing host immunity and disease prevention in culture fish [5].

Riverine Catfish Pangasius hypophthalmus is considered as one of the most successful aquaculture species due to its relative ease in culture, fast-growing fish, high-market demand, and suitability to local climate conditions [6]. Although, P. hypophthalmus is highly tolerant to adverse environmental conditions [7]. However, the occurrence of diseases in $P$. hypophthalmus farming has become a major problem causing significant losses to the farmers [8], due to lack of diagnostic support and appropriate therapeutants [9]. Therefore, the maintenance of fish in health, and enhancement of the fish innate immunity are the primary concern.

The use of seaweeds extracts is inexpensive than chemicals and antibiotics and have little effects on nature, humans, and fish and containing properties that modulate the fish immune system. Brown seaweeds such as Sargassum spp. have been studied and has potential antimicrobial agents and as natural immunostimulant in aquaculture industry for treated microbial diseases in infected finfish and crustaceans [10-14]. Several studies demonstrated that natural extracts from seaweeds can modify immune response against infectious diseases in fish. Therefore, the aim of this study was to determine the effects of hot-water extract (HWE) of Sargassum oligocystum on growth performance, and immune response using $P$. hypophthalmus as an experimental model. Specifically, we tested the hypothesis that seaweed extract could be used to enhance the growth and immune response in fish.

\section{MATERIAL AND METHODS}

\section{Experimental animals}

Around 4,000 P. hypophthalmus fingerlings were obtained from Frame farm at Muñoz, Nueva, Ecija and were shipped to the aquaculture experimental laboratory room of Institute of Fisheries, Isabela State University, Echague, Isabela. The experimental animals were placed in plastic container (100 L) capacity and were acclimatized under laboratory condition for two weeks prior to the conduct of the experiments. During the acclimatization period, the experimental animals received formulated diets to satiation twice daily $(1000 \mathrm{H}$ and $1600 \mathrm{H}$ ). The experimental animals were screened for the presence of pathogen before the start of the experiments.

\section{Collection site and preparation of the hot-water extract of S. oligocystum}

S. oligocystum was collected by scuba diving and handpicking from the rocky substratum at depth of 1-3 $\mathrm{m}$ along the subtidal areas at Diora-Zinungan, Santa Ana (16 $46^{\prime} 79^{\prime \prime} \mathrm{N}$ lat, $121^{\circ} 23^{\prime} 00.48^{\prime \prime} \mathrm{E}$ long) Cagayan, Philippines. The hot-water extract (HWE) of $S$. oligocystum was prepared based on the method described by $[15,19]$ with some modifications. Briefly $50 \mathrm{~g}$ of dried powdered seaweeds were mixed with $500 \mathrm{ml}$ of deionized distilled water and cover with plastic wrap. The suspension was boiled for three (3) hours in a water bath. After boiling, the solid particles were removed by straining and squeezing using cheese cloth and the suspension was filtered using nylon mesh and the filtrate was kept frozen at $-80^{\circ} \mathrm{C}$ for $24 \mathrm{~h}$ and lyophilized under reduced pressure for $48 \mathrm{~h}$. 


\section{Diet preparation}

The HWE of S. oligocystum was dissolved in distilled water at concentrations of 10,30, $50 \mathrm{~g} / \mathrm{L}$ of water. The solvent of distilled water and HWE of $S$. oligocystum was sprayed at a rate of $100,300,500 \mathrm{ml} \mathrm{kg}-1$ of commercial feed. The four experimental diets were air-dried at room temperature for $24 \mathrm{~h}$. The prepared diets were packed, labeled and stored in a refrigerator $\left(4^{\circ} \mathrm{C}\right)$ until use.

\section{Experimental treatment and set-up}

The experiment was conducted following Completely Randomized Design (CRD). All the treatments of the different experiments have three replicates. Survival and growth of each experimental animal were monitored every two weeks. The length and weight of each experimental animal in each treatment were recorded and served as a basis for the adjustment of feed rate.

\section{Growth trial experiments}

There were four experimental treatments in the study and each treatment was replicated three times. The fish were stock in $100 \mathrm{I}$ capacity plastic containers. Feeding trials were carried out under the laboratory condition for 12 weeks. One group for each set-up served control (commercial feeding), the remaining three groups in each set-up were fed with experimental diets containing of $100,300,500 \mathrm{mg} \mathrm{kg}^{-1} \mathrm{HWE}$ of $S$. oligocystum for the dietary administration at $5 \%$ of their total body weight. Water management was done thrice weekly. Growth of each experimental animals were monitored every two weeks. At the end of the feeding trial, the growth parameters such as weight gain (WG), survival (S), daily growth rate (DGR), feed conversion ratio (FCR), were calculated by using following formulae:

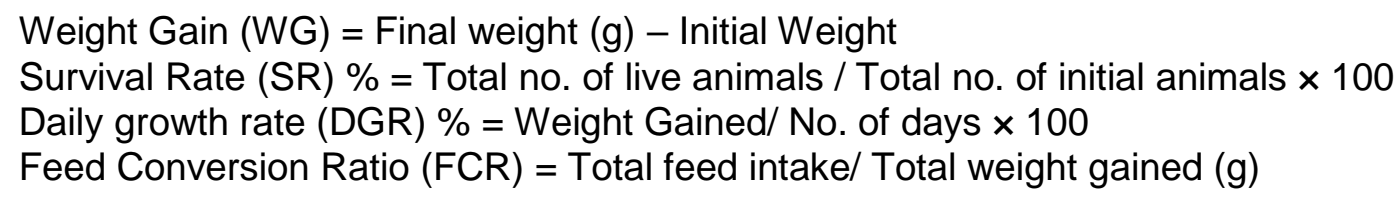

\section{Collection of blood}

Six fish was randomly collected from each treatment at days $1,3,5$, and 7 post-administration of hot water extract. To minimize handling stress, the fish was anesthetized by immersion in water containing $100 \mathrm{mg} \mathrm{I}^{-1}$ tricaine-s methane sulfonate (MS 222). Whole blood $(1 \mathrm{ml})$ was collected from the caudal vein of each fish using syringes $(1 \mathrm{ml})$ with 25-gauge needles that was rinsed with $0.2 \mathrm{M}$ Ethylenediaminetetraacetic acid (EDTA) as anticoagulant. A portion of a dorsal fin of $P$. hypophthalmus was cut after blood collection for identification purposes. The collected blood was transferred in $0.5 \mathrm{ml}$ heparin vacutainer tube with EDTA and maintained at low temperature and immediately transferred to Diagnostic Prime Laboratory, San Fabian, Echague, Isabela Philippines using Rayto Auto Hematology Analyzer (RT-7600) for further analyses.

\section{Statistical analysis}

The effect of treatment on growth, and immune parameter was evaluated using a one-way analysis of variance (ANOVA) with treatment, weeks as variables. A multiple-comparison using (Tukey's) test was determine significant differences among the treatment using the (SPSS, 21.0). Data are reported as mean \pm standard deviations. Statistical significant of differences required that $p<0.05$. 


\section{RESULTS AND DISCUSSION}

\section{Growth performance}

Dietary administration seaweeds as immunostimulant is a safe, eco-friendly alternative approach against diseases for the aquaculture industry. Hot-water extract administration from several species of Sargassum spp. has been reported to promote growth performance immunity and disease resistance of various finfish against selected aquaculture pathogens [16-19]. The immunostimulatory effects of the hot-water seaweed extracts of Sargassum oligocystum via oral administration were investigated in this study. The growth performance of $P$. hypophthalmus fed with the different diets containing HWE of $S$. oligocystum in terms of mean initial and final length (cm), initial and final weight (g), WG (g), SR (\%), DGR (\%) and FCR is shown in Table 1.

The final length, final weight, weight gain, daily growth rate, feed conversion ratio significantly increased in the experimental fish fed with HWE of S. oligocystum containing diet 300 and $500 \mathrm{mg} \mathrm{kg}^{-1}$ when compared with control diets after 12 weeks of feeding trials. However, no significant differences on the FCR and SR were found among treatment. Grouper, E. coioides fed Sargassum cristaefolium containing diets at $0.5,1$ and $2 \mathrm{~g} / \mathrm{kg}$ significantly improved growth performance of the fish [18]. Moreover, [20], reported that a significant improvement in growth performance was found in the snakehead $C$. striatus fry fed diets containing 5\% Ulva spp. which conform to the present investigation. The use of Porphyra purpurea at high inclusion levels (16\% and $33 \%$ ), as an ingredient for mullet (Chelon labrosus) diets suppressed growth performance and feed utilization efficiency [21]. In another study by [22], revealed that the dietary supplementation of selected microalgae such as Gracilaria spp., Ulva spp., and Fucus spp., at 2.5 and $7.5 \%$ levels, in diets for European seabass had no effect on final body weight, DGI, FCR and PER which in contrast to our result. This difference in result might be due to types of fish species used, age, feeding duration, source of the immunostimulant, stocking densities, water quality or other environmental factors [23-24].

Table 1. Growth parameters of Riverine catfish $P$. hypophthalmus fed with experimental diets containing 100,300 or $500 \mathrm{mg} \mathrm{kg}-{ }^{1}$ HWE S. oligocystum.

\begin{tabular}{|c|c|c|c|c|}
\hline \multirow[t]{3}{*}{ Parameters } & \multicolumn{4}{|l|}{ Feeds } \\
\hline & \multirow{2}{*}{$\begin{array}{l}\text { Control } \\
\text { Feed } 1 \\
\left(0 \mathrm{mg} \mathrm{kg}-{ }^{1} \mathrm{HWE}\right)\end{array}$} & \multicolumn{3}{|c|}{ Experimental Treatments } \\
\hline & & $\begin{array}{l}\text { Feed } 2 \\
\left.\text { (100 mg kg- }{ }^{1} \mathrm{HWE}\right)\end{array}$ & $\begin{array}{l}\text { Feed } 3 \\
\left(300 \mathrm{mg} \mathrm{kg}^{-1} \mathrm{HWE}\right)\end{array}$ & $\begin{array}{l}\text { Feed } 4 \\
\left(500 \mathrm{mg} \mathrm{kg}^{-1} \mathrm{HWE}\right)\end{array}$ \\
\hline Length (Initial) cm & $6.66 \pm 0.90^{\mathrm{a}}$ & $7.53 \pm 0.08^{\mathrm{a}}$ & $7.43 \pm 0.26^{\mathrm{a}}$ & $7.41 \pm 0.33^{\mathrm{a}}$ \\
\hline Length (Final) cm & $22.13 \pm 1.46^{\mathrm{b}}$ & $23.37 \pm 0.12^{\mathrm{ab}}$ & $24.13 \pm 0.72^{\mathrm{ab}}$ & $24.52 \pm 0.78^{\mathrm{a}}$ \\
\hline Weight (Initial) g & $5.3 \pm 0.26^{\mathrm{a}}$ & $5.56 \pm 0.15^{\mathrm{a}}$ & $5.46 \pm 0.15^{\mathrm{a}}$ & $5.38 \pm 0.82^{\mathrm{a}}$ \\
\hline Weight (Final) g & $38.53 \pm 0.88^{c}$ & $40.43 \pm 1.66^{\mathrm{bc}}$ & $42.37 \pm 1.14^{\mathrm{ab}}$ & $44.23 \pm 1.51^{\mathrm{a}}$ \\
\hline Weight gain (g) & $33.22 \pm 0.95^{\mathrm{C}}$ & $34.87 \pm 1.51^{\mathrm{bc}}$ & $36.9 \pm 1.22^{\mathrm{ab}}$ & $37.85 \pm 2.09^{\mathrm{a}}$ \\
\hline Survival rate (\%) & $100 \pm 0.00^{\mathrm{a}}$ & $100 \pm 0.00^{a}$ & $100 \pm 0.00^{\mathrm{a}}$ & $100 \pm 0.00^{\mathrm{a}}$ \\
\hline Daily growth rate (\%) & $39.56 \pm 1.13^{\mathrm{c}}$ & $41.51 \pm 1.80^{\mathrm{bc}}$ & $43.93 \pm 1.46^{\mathrm{ab}}$ & $46.25 \pm 2.48^{\mathrm{a}}$ \\
\hline Feed conversion ratio & $2.26 \pm 0.23^{\mathrm{a}}$ & $2.25 \pm 0.07^{\mathrm{a}}$ & $2.19 \pm 0.33^{\mathrm{a}}$ & $2.18 \pm 0.11^{\mathrm{a}}$ \\
\hline
\end{tabular}

Each value is mean \pm of triplicate observations. Mean values having the same superscript are not significantly different $(p>0.05)$. 


\section{Haematological profile}

Hematological parameters were evaluated to determine the immune response of Pangasius hypophthalmus. Blood of fish may be one of the indicators for diagnosis of fish diseases. Thus haematological parameters are an important tool for determining health status [25-26], and fish health diagnosis [27]. In the study, the white blood cell (WBC) count of $P$. hypophthalmus that fed diets containing of HWE of $S$. oligocystum at $500 \mathrm{mg} \mathrm{kg}^{-1}$ was significantly higher than the fish fed the control diet over 1-7 days (Figure 1), that confirms the previous findings [17]. WBC is important cells and plays a great role in the immune system of the fish, because of their main defensive function to overcome the toxic stress [28], and defense against infection [29]. The increase in WBC of fish was suggested to indicate an alteration in defense mechanism against the action of the highly toxic and the bioaccumulated heavy metals in fish tissues [30]. In addition, a measurable increase in WBC of fish is a function of immunity and response to vulnerable illness and disease [31].

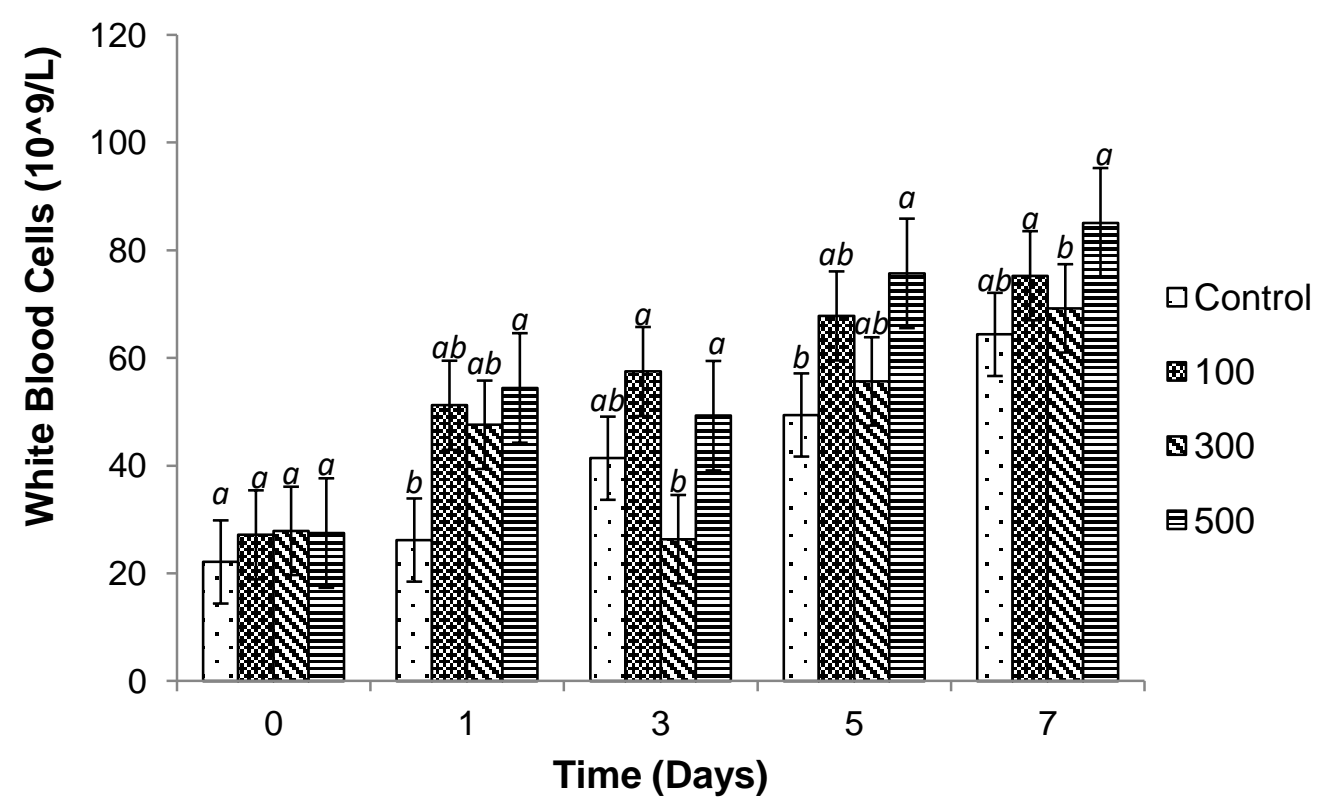

Figure 1. Mean $( \pm$ S.E.) white blood cell count of $P$. hypophthalmus that received HWE $S$. oligocystum at 100,300 or $500 \mathrm{mg} \mathrm{kg}-1$. Each bar represents mean value from six determinations with standard error. Data at the same exposure time with different letters are significantly different $(p<0.05)$ among treatments.

The red blood cell (RBC) count of $P$. hypophthalmus that fed diets containing of HWE of S. oligocystum at was significantly higher than the fish fed the control diet over 1, 3 and 7 days, (Figure 2), which is similar to the study of [32]. The increase of erythrocyte or RBC count is an indication of high oxygen carrying capacity of blood which is the characteristic of fishes capable of aerial respiration and with high activity [33]. However, a decline in hemoglobin content and red blood cells showed anemic characters of the fish which leads to hemodilution and immunosuppression due to which infection grows faster resulting in fish mortality [34]. 


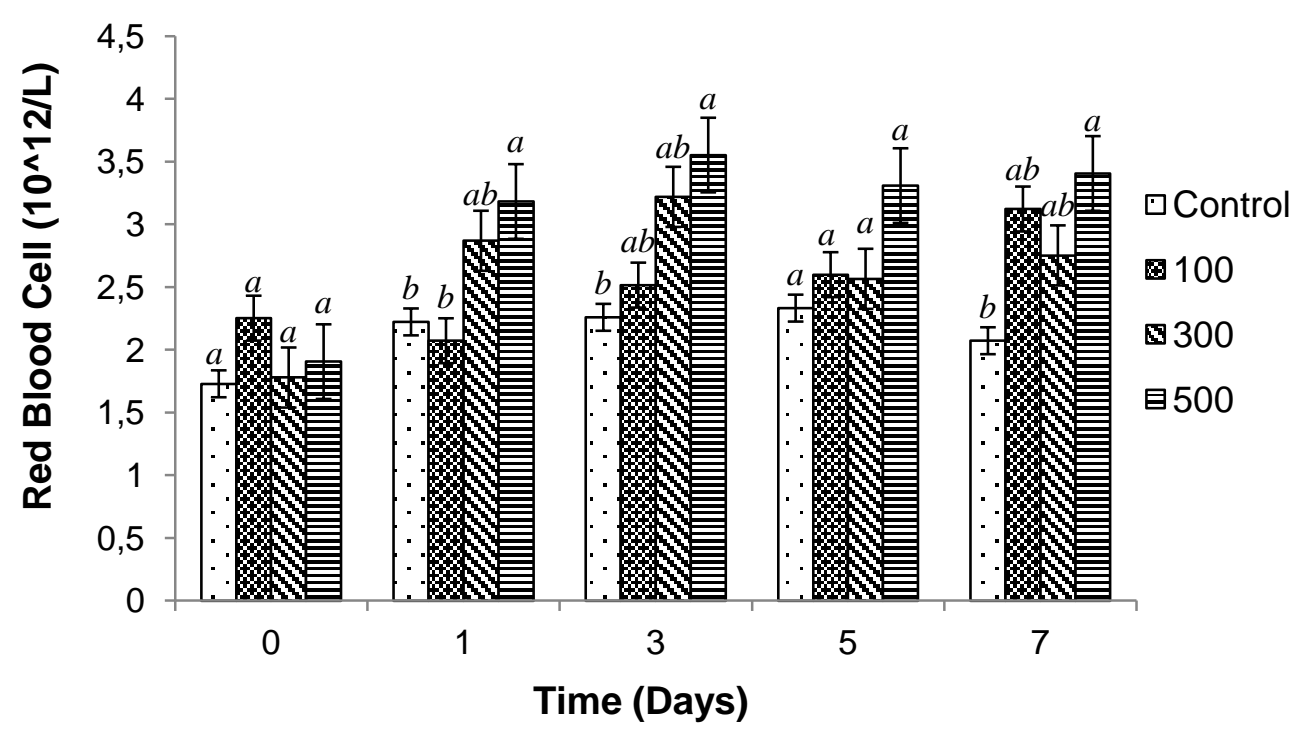

Figure 2. Mean $( \pm$ S.E.) red blood cell count of $P$. hypophthalmus that received HWE $S$. oligocystum at 100,300 or $500 \mathrm{mg} \mathrm{kg}-^{-}$. Each bar represents mean value from six determinations with standard error. Data at the same exposure time with different letters are significantly different $(p<0.05)$ among treatments.

The hematocrit count of $P$. hypophthalmus that fed diets containing of HWE of $S$. oligocystum at was significantly higher than the fish fed the control diet over 1, 5 and 7 days, respectively (Figure 3). Similar results were observed by [35]. A decline in RBC and hematocrit combined with signs of anaemia and cases of proliferative kidney disease [36]. In addition, decreased RBC counts and hematocrit indicated that erythrocytes were being affected or destroyed with the infection [37]. The normal hematocrit values usually fall within the range of $20-35 \%$ and are rarely greater than $50 \%$ for fish. However, since transport of metals in fish occurs through the blood where the ions are usually bound to proteins and pollutants generally produce relatively rapid changes in blood characteristics of fish [38].

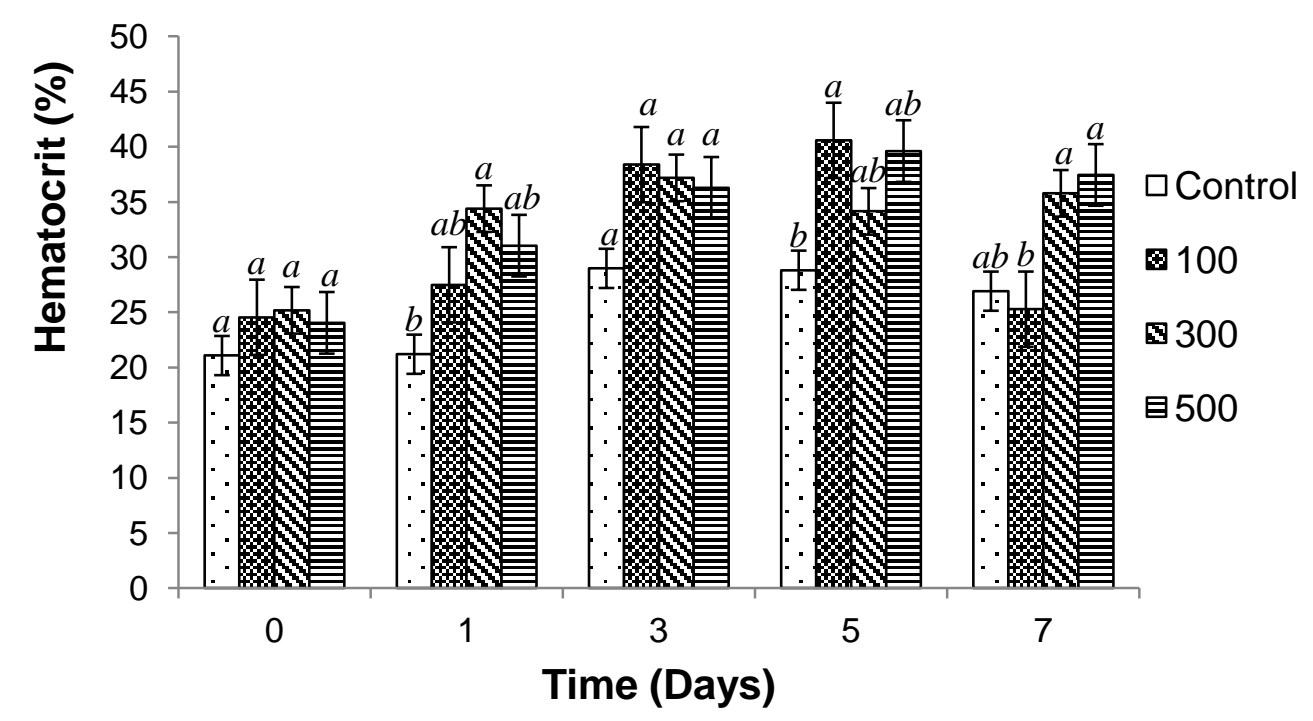

Figure 3. Mean ( \pm S.E.) hematocrit count of $P$. hypophthalmus that received HWE $S$. oligocystum at 100,300 or $500 \mathrm{mg} \mathrm{kg}{ }^{-1}$. Each bar represents mean value from six determinations with standard error. Data at the same exposure time with different letters are significantly different $(p<0.05)$ among treatments. 
The Hemoglobin count of $P$. hypophthalmus that fed diets containing of HWE of $S$. oligocystum at $100 \mathrm{mg} \mathrm{kg}-{ }^{1}$ and $500 \mathrm{mg} \mathrm{kg}-{ }^{1}$ was significantly higher than the fish fed the control diet over 1-7 days (Figure 4). The Hemoglobin count from the present study was more or less similar to the findings of [39]. Decrease in hemoglobin trend may be a result of swelling of RBCs as well as poor mobilization of hemoglobin from spleen [34]. Prolonged reduction in hemoglobin content is deleterious to oxygen transport and degeneration of the erythrocytes could be due to pathological condition in fish exposed to toxicants. The decrease in hemoglobin corresponds with the decrease in dissolved oxygen; an indication that the decrease in hemoglobin resulted in hemodulation [40].

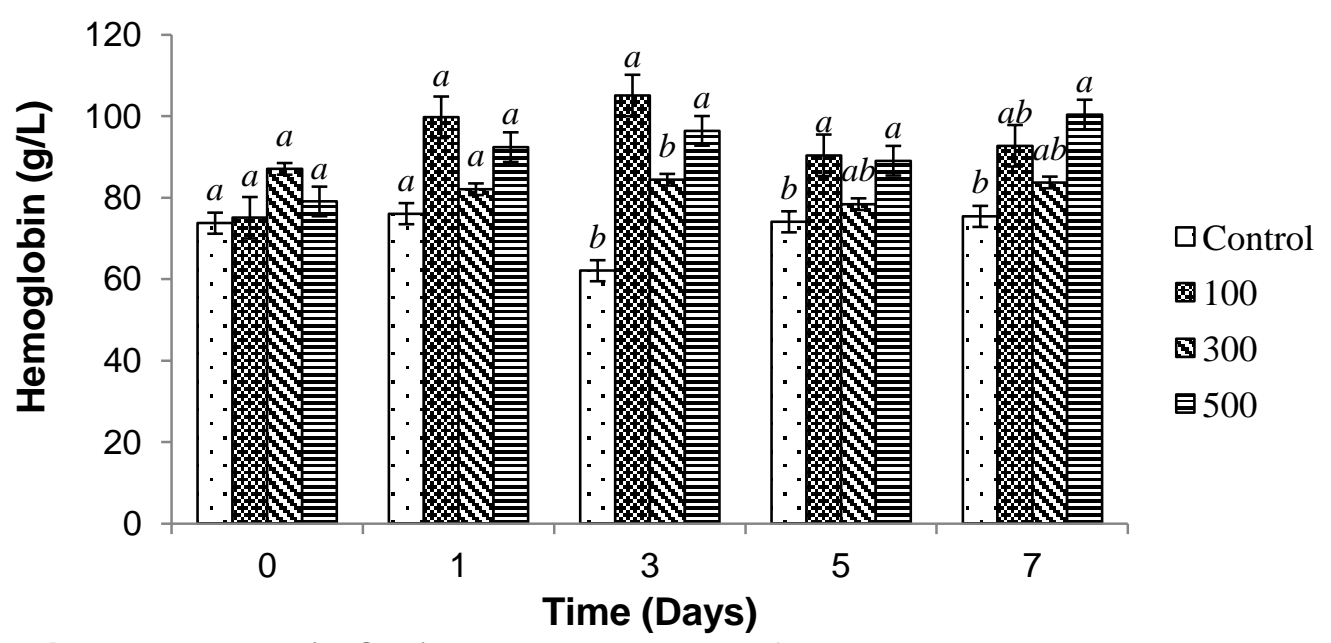

Figure 4. Mean ( \pm S.E.) hemoglobin count of $P$. hypophthalmus that received HWE $S$. oligocystum at 100,300 or $500 \mathrm{mg} \mathrm{kg}-^{1}$. Each bar represents mean value from six determinations with standard error. Data at the same exposure time with different letters are significantly different $(p<0.05)$ among treatments.

The platelet count of $P$. hypophthalmus that fed diets containing of HWE of $S$. oligocystum at was significantly higher than the fish fed the control diet over 1, 3 and 7 days, (Figure 5). Platelets are also surprisingly multifunctional and are involved in many pathophysiological processes including haemostasis and thrombosis, clot retraction, vessel constriction and repair, including promotion of atherosclerosis, host defense and even tumour growth/metastasis [41].

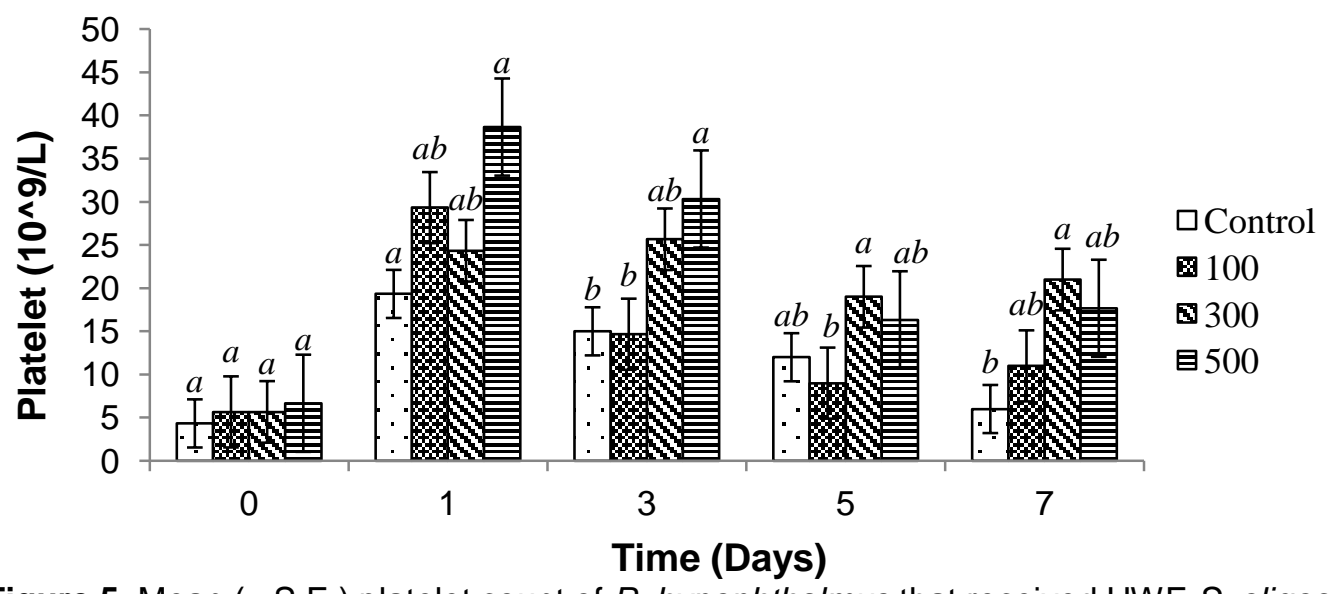

Figure 5. Mean ( \pm S.E.) platelet count of $P$. hypophthalmus that received HWE S. oligocystum at 100,300 or $500 \mathrm{mg} \mathrm{kg}{ }^{-}$. Each bar represents mean value from six determinations with standard error. Data at the same exposure time with different letters are significantly different $(p<0.05)$ among treatments. 
For effective use of immunostimulants, timing, dosage, route of administration, and physiological conditions of fish should always be considered [42]. In addition, polysaccharides present in seaweeds may activate the non-specific immune response in both finfish and crustaceans. The blood composition in fish might be changed by dietary treatment, malnutrition and disease condition [43], and the changes in hematological profile in response to stressing agents are indicators of the stressful stage of fish [44].

\section{CONCLUSION}

Overall, our results indicate that the used HWE of S. oligocystum improves growth and immune responses in $P$. hypophthalmus and it can be used as a natural immunostimulant and may be a valuable tool to increase the immune-competency of valuable aquaculture fish species.

Funding: This study was funded by a grant from the Department of Agriculture - Bureau of agricultural Research (DA-BAR).

Conflicts of Interest: The authors declare no conflict of interest.

\section{REFERENCES}

1. Ai Q, Xu H, Mai K, Xu W, Wang J, Zhang W. Effects of dietary supplementation of Bacillus subtilis and fructooligosaccharide on growth performance, survival, non-specific immune response and disease resistance of juvenile large yellow croaker, Larimichthys crocea. Aquaculture. 2011;317:155-61.

2. Balcázar JL, de Blas I, Ruiz-Zarzuela I, Cunningham D, Vendrell D, Múzquiz JL. The role of probiotics in aquaculture. Vet Microbiol. 2006;114:173-86.

3. Le TX, Munekage $\mathrm{Y}$, Kato SI. Antibiotic resistance in bacteria from shrimp farming in mangrove areas. Sci Total Environ. 2005;349:95-105.

4. Rico A, Satapornvanit K, Haque MM, Min J, Nguyen PT, Telfer TC, Van den Brink PJ. Use of chemicals and biological products in Asian aquaculture and their potential environmental risks: a critical review. Rev Aquacult. 2012;4:75-93.

5. Kim, M.C.; Harikrishnan, R.; Heo, M.S. Effects of a probiotic and herbal supplemented diet on growth, blood biochemistry, and innate immune response of Olive flounder and Parrot fish. Isr J Aquacult-Bamidgeh. 2012;64:711.

6. Rahman MM, Islam MS, Halder GC, Tanaka M. Cage culture of Sutchi catfish, Pangasius sutchi (Fowler 1937): effects of stocking density on growth, survival, and yield and farm profitability. Aquac Res. 2005;1-7.

7. Belton B, Haque MM, Little DC, Sinth LX. Certifying catfish in Vietnam and Bangladesh: Who will make grade and will it matter? Food Policy. 2011;36:289-99.

8. Faruk Md AR. Disease and health management of farmed exotic catfish Pangasius hypopthalmus in Mymensingh district of Bangladesh, In: Bondad-Reantaso MG, Mohan CV, Crumlish M, Subasinghe RP, Eds. Diseases in Asian Aquaculture VI. Manila (Philippines): Fish Health Section, Asian Fisheries Society; 2008. p. 193-204. co

9. Nahar S, Rahman MM, Ahmed GU, Faruk AR. Isolation, identification, and characterization of Aeromonas hydrophila from juvenile farmed Pangasius (Pangasianodon hypophthalmus). Int $\mathrm{J}$ Fish Aquat Stud. 2016;4:52-60.

10. Baleta FN, Laureta LV, Apines Amar MJS, Padilla PIP, Quinitio GF Biological activity of extract Sargassum oligocystum (Magnaye) against aquaculture pathogenic bacteria. Isr J 
Aquacult-Bamidgeh. 2011;63:667-71.

11. Dashtiannasab A, Kakoolaki S, Sharif Rohani M, Yeganeh V. In vitro effects of Sargassum latifolium (Agardeh, 1948) against selected bacterial pathogens of shrimp. Iran J Fish Sci. 2012;11:765-75.

12. Mahianeh A, Ghaednia B, Mirbakhsh M, Velayatzadeh M, Mohammadi E, Jafari M, Kamrani E, Ghaedifard B. The effects of brown alga, Sargassum glaucescensas (Agardeh, 1948) against selected bacterial, fungal and yeast pathogens of shrimp. Int J Biosci. 2014;5:399-405.

13. Baleta FN, Bolaños JM, Ruma OC, Baleta AN, Cairel JD. Phytochemical screening and antimicrobial properties of Sargassum oligocystum and Sargassum crassifolium extracts. J Med Plants Stud. 2017;5,382-87.

14. Bolaños JM, Baleta FN, Cairel JD. Antimicrobial properties of Sargassum spp. (Phaeophyceae) against selected aquaculture pathogens. Int J Curr Microbiol App Sci. 2017; 6:024-1037.

15. Fujiki $\mathrm{K}$, Matsuyama $\mathrm{H}$, Yano $\mathrm{T}$. Effect of hot-water extracts from marine algae on resistance of carp and yellowtail against bacterial infections. Sci Bull. 1992;47:137-41.

16. Ghaednia B, Mehrabi MR, Mirbakhsh M, Yeganeh V, Hoseinkhezri P, Garibi G, Ghaffar Jabbari A. Effect of hot-water extract of brown seaweed Sargassum glaucescens via immersion route on immune responses of Fenneropenaeus indicus. Iran J Fish Sci. 2011;10:616-30.

17. Kanimozhi S, Krishnaveni M, Deivasigmani B, Rajasekar T, Priyadarshni P. Immunomostimulation effects of Sargassum whitti on Mugil cephalus against Pseudomonas fluorescence. Int J Curr Microbiol App Sci. 2013;2:93-103.

18. Wong SL, Gao LH, Chang CC, Cheng W. The effect of hot-water extract of Sargassum cristaefolium on growth, innate immune responses and resistance of Grouper, Epinephelus coiodes. J Fish Soc Taiwan. 2013;40:11-26.

19. Baleta FN, Chiarri GM. Effect of Sargassum oligocystum hot-water extract on innate immune response and survival of Summer flounder Paralichthys dentatus to Vibrio harveyi challenge. Isr J Aquacult-Bamidgeh. 2016;68:1289-301.

20. Hashim R, Saat MAM. The utilization of seaweed meals as binding agents in pelleted feeds for snakehead (Channa striatus) fry and their effects on growth. Aquaculture. 1992;108:299-308.

21. Davies SJ, Brown MT, Camilleri M. Preliminary assessment of the seaweed Porphyra purpurea in artificial diets for thick-lipped grey mullet (Chelon labrosus). Aquaculture. 1997;152:249-58.

22. Peixoto MJ, Salas-Leitón E, Pereira LF, Queiroz A, Magalhães F, Pereira R, Abreu H, Reis PA, Goncalves JFM, de Almeida, Ozorio ROA. Role of dietary seaweed supplementation on growth performance, digestive capacity and immune and stress responsiveness in European seabass (Dicentrarchus labrax). Aquac Rep. 2016;3:189-97.

23. Cook MT, Hayball PJ, Hutchinson W, Nowak BF, Hayball JD. Administration of a commercial immunostimulant preparation, Eco Activa _ as a feed supplement enhances macrophage respiratory burst and the growth rate of snapper (Pagrus auratus, Sparidae (Bloch and Schneider) in winter. Fish Shellfish Immun. 2003;14:333e45.

24. Kumari J, Sahoo PK. Dietary b-1,3 glucan potentiates innate immunity and disease resistance of Asian catfish, Clarias batrachus (L.). J Fish Dis. 2006;29:95e101.

25. Klinger CR, Blazer SV, Echevarria C. Effects of dietary lipid on the hematology of Channel catfish, Ictalurus punctatus. Aquaculture. 1996; 47:225-33.

26. Mohammed AK, Sambo AB. Haematological assessment of the Nile tilapia Oreochromis 
niloticus exposed to sublethal concentrations of portland cement powder in solution. Int $\mathrm{J}$ Zool Res. 2007;4:48-52.

27. Chen CY, Wooster GA, Bowser PR. Comparative blood chemistry and histopathology of tilapia infected with Vibrio vulnificus or Streptococcus iniae or exposed to carbon tetrachloride, gentamicin, or copper sulfate. Aquaculture. 2004;239:421-43.

28. Sahar M, Singh IJ. Effect of cypermethrin on some hematological parameters and prediction of their recovery in a freshwater Teleost, Cyprinus carpio. Afr J Environ Sci Technol. 2013;7:852-856.

29. Lebelo SL, Saunders DK, Crawford TG. Observations on blood viscosity in striped bass, Morone saxtilis (Walbaum) associated with fish hatchery conditions. Kansa Acad Sci. 2001;104:183-94.

30. Zagloul $\mathrm{KH}$. Usage of zinc and calcium in inhibiting the toxic effect of copper on the African catfish; Clarias gariepenus. J Egypt Gerol School Zool. 2001;35:99-120.

31. Akinwande AA, Moody FO, Sogbesan OA, Ugwumba AAA, Ovie SO. Haematological reponse of Heterobranchus longifilis fed varying dietary protein levels. In: Proceeding of the 19th Annual Conference of the Fisheries Society of Nigeria; 2004; Ilorin. p. 715-18.

32. Mohsen AT, Mohammad HA, Medhat EAS, Saleh FMS. Use of green tea, Camellia sinensis L, in practical diet for growth and production of Nile tilapia, Oreochromis niloticus (L) against Aeromonas hydrophila infection. J World Aquacul Soc. 2010; 41:203-13.

33. Jimoh WA, Aderolu AZ, Ayeloja AA, Shodamola MO. Hematological response of Clarias gariepenus (Burchell 1822) fed diets containing Luffah cylindricql seed meal. In: Proceedings of the $27^{\text {th }}$ Annual Conference and Biennial General Meeting of the Fisheries Society of Nigeria; 2012; Bayelsa State. p. 392-96.

34. Rekha C, Andleef F, Lone SA, Ganaie SA. Hematological and histological investigations on healthy and Saprolegnia sp. infected Clarias gariepinus (burchell1822). Int J Exp Pharmacol. 2014;4:97-100.

35. Ranzani-Paiva MJT, Ishikawa CM, das Eiras AC, da Silveira VR. Effects of an experimental challenge with Mycobacterium marinum on the blood parameters of Nile tilapia, Oreochromis niloticus (Linnaeus, 1757). Braz Arch Biol Technol. 2004;47: 945-53.

36. Hoffmann R, Lommel R. Haematological studies in proliferative kidney disease of rainbow trout, Salmo gairdneri Richardson. J Fish Dis. 1984;7: 323-6.

37. Harikrishnan R, Rani MN, Balasundaram C. Hematological and biochemical parameters in Common carp Cyprinus carpio, following herbal treatment for Aeromonas hydrophila infection. Aquaculture. 2003;221:4-50.

38. Ayandiran TA, Fawole OO, Adewoye SO, Ogundiran MA. Bioconcentration of metals in the head capsule and skeleton of Clarias gariepinus exposed to sublethal concentrations of soap and detergent effluents. J Agric Biol. 2010;2151-7525.

39. Abalaka SE. Evaluation of haematology and biochemistry of Clarias gariepinus as biomarkers of environmental pollution in Tiga dam, Nigeria. Braz Arch Biol Technol. 2013;56:371-76.

40. Gafaar AY, El-manakhy EM, Soliman MK, Soufy H, Monas Z, Mohammed SG. Some pathological, biochemical and hematological investigation on Nile tilapia (Oreochromis niloticus) following chronic exposure to edifenphos pesticide. J Am Sci. 2010;6:542-51.

41. Harrison P. Platelet function analysis. Els Blood Rev. 2005;19:111-23.

42. Kunttu HMT, Valtonen ET, Soumalainen LR, Vielma J, Jokinen IE. The efficacy of two 
immunostimulants against Flavobacterium columnare infection in juvenile Rainbow trout (Onchorhynchus mykiss). Fish Shellfish Immun. 2009;26: 850-57.

43. Feist SW, Longshaw M. Myxosporiodiosis of fish and the bryozoan link with proliferate kidney diseases (PKD) of salmonids. J Fish Dis. 2000;1:91-108.

44. Bello-Olusoji OA, Omoare VY, Nwana LC. Comparative studies on the haematological characteristics of pond cultured and wild tilapia (Oreochromis niloticus) Linnaeus, 1857. Nigerian J For. 2006;36:134-41.

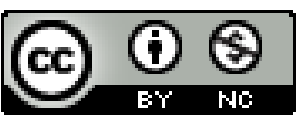

(C) 2018 by the authors. Submitted for possible open access publication under the terms and conditions of the Creative Commons Attribution (CC BY NC) license (https://creativecommons.org/licenses/by-nc/4.0/). 